fractures: Organization of treatment. Clin Plast Surg.;16:105-114

7. Lâm Hoài Phương. (1997) Kỹ thuật điều trị tạo hình trong chấn thương và di chứng gãy cung tiếp gò má, Kỷ yếu công trình nghiên cứu khoa học
Răng hàm mặt,73-80.

8. Nguyê̂n Quốc Trung (1997) Nghiên cứu hình thái lâm sàng, phương pháp điêu trị gãy xương gò má, cung tiếp tại viện Răng Hàm Mặt Hà Nội.

\title{
ĐộT BIẾN KRAS TRONG UNG THƯ PHỔI KHÔNG TẾ BÀO NHỎ TẠI BỆNH VIỆN K
}

\begin{abstract}
TÓM TẮT
Mục tiêu: Đánh giá tình trạng đột biến KRAS trên bênh nhân UTPKTBN tại bệnh viện Kं. Đối tượng và phương pháp: Mô tả hồi cứu 931 mẫu xét nghiệm NGS, trong đó có 758 mấu mô của bênh nhân ung thư phổi không tế bào nhỏ tại Bệnh viện $\mathrm{K}$ từ 1/2019. Xét nghiệm được thực hiện tại Viện di truyền TPHCM bằng kỹ thuật Massively parallel DNA by next generation sequencing technology. Kết quả: Đột biến KRAS chiếm tỷ lệ 20,1\%; chủ yếu xảy ra ở nam giới chiếm tỷ lệ $92 \%$. 9\% đôtt biến KRAS xuất hiện đồng thời với một đột biến khác (EGFR, ALK, BRAF, MET. PI3KCA). Đột biến ở Codon 12 chiếm 81,3\%; codon 13 chiếm 18,7\%. Kết luận: Tình trạng đột biến KRAS trong khảo sát tại bệnh viện $\mathrm{K}$ tương đồng với các dữ liệu trong y văn
\end{abstract} biến KRAS

Tư khóa: Ung thư phổi không tế bào nhỏ, đột

\section{SUMMARY}

\section{KRAS MUTATION CHARACTERISTICS IN SMALL CELLULAR NON-ACCOUNT CANCER AT K HOSPITAL}

Objective: To evaluate the KRAS mutation in non-small cell lung cancer patients at $\mathrm{K}$ hospital. Objects and methods: Retrospective description of 931 NGS test samples, including 758 tissue samples from non-small cell lung cancer patients at $\mathrm{K}$ Hospital from 1/2019. The test is done at HCMCT Genetics Institute using Massively parallel DNA by next generation sequencing technology. Results: KRAS mutation accounted for $20.1 \%$; mainly occurs in men, accounting for $92 \%$. $9 \%$ of the KRAS mutation occurs concurrently with another mutation (EGFR, ALK, BRAF, MET. PI3KCA). Mutations in Codon 12 accounted for $81.3 \%$; codon 13 accounts for $18.7 \%$. Conclusion: The KRAS mutation in the $\mathrm{K}$ hospital survey is consistent with the data in the literature

Keywords: Non-small cell Lung cancer, KRAS mutation.

\section{I. Đă̆T VẤN ĐỀ}

Ung thư phổi không tế bào nhỏ (UTPKTBN)

*Bệnh viện $K$ Trung ương

Chịu trách nhiệm chính: Nguyễn Thị Thái Hòa

Email: bshoabvk@gmail.com

Ngày nhận bài: 5/2/2021

Ngày phản biện khoa học: 5/3/2021

Ngày duyệt bài: 22/3/2021
Nguyễn Thị Thái Hoà*

chiếm tỷ lệ 80 - 85\% trong các ung thư phổi nói chung. Trong hai thập niên gần đây, điều trị UTPKTBN đã có những tiến bộ vượt bậc, nhất là đối với giai đoạn tái phát và di căn. Trong các phương pháp nâng cao hiệu quả điều trị ung thư phổi, điều trị đích đã đem lại nhiều lợi ích, bao gồm điều trị nhắm đích EGFR, nhắm đích $A L K$, ROS1, BRAF... Chính bởi vậy, với các bệnh nhân UTPKTBN giai đoạn tiến xa, xét nghiệm đột biến gen đã trở thành thường quy để có lựa chọn điều trị thích hợp, đặc biệt đối với thể mô bệnh học không phải loại tế bào vảy. Với các thống kê tại Việt Nam, đột biến EGFR chiếm tỷ lệ cao nhất với, đột biến KRAS đứng thứ hai, chiếm tỷ lệ là $20 \%$ [1].

KRAS là một trong số 3 gen của gia đình RAS (cùng với HRAS và NRAS), nằm ở nhánh ngắn của nhiễm sắc thể 12 . Đột biến RAS xuất hiện khoảng 30\% trong số các ung thư ở người, trong đó đột biến KRAS chiếm tỷ lệ chủ yếu [2].

Trong UTPKTBN, đột biến KRAS thường xảy ra ở Codon 12, ít găp hơn có thể thấy ở Codon 13 hoăc 61 . Đột biến này hay gặp ở thể mô bệnh học UTBM tuyến chiếm khoảng 16-40\% $[3,4]$, hiếm gặp ở UTBM tế bào vảy, và không gặp ở loại tế bào nhỏ. Đột biến KRAS thường gặp hơn ở bệnh nhân hút thuốc [5].

Một số nghiên cứu cho thấy đột biễn KRAS thường liên quan tới thời gian đáp ứng điều trị và sống thêm ngắn[6]. Đột biến KRAS có thể làm giảm đáp ứng của erlotinib và gefetinib [7].

Xét nghiệm giải trình tự gen thế hệ mới cho phép xác định đột biến KRAS với độ nhạy và đặc hiệu cao. Mục tiểu của nghiên cứu này là: "Đánh giá tình trạng đột biến KRAS trên bệnh nhân UTPKTBN tại bệnh viện K"

\section{II. ĐỐI TƯỢNG VÀ PHƯƠNG PHÁP NGHIÊN CỨU}

2.1. Đối tượng nghiên cứu. Mẫu xét nghiệm làm NGS từ 1/2019 của bệnh nhân ung thư phổi không tế bào nhỏ điều trị tại Bệnh viện $\mathrm{K}$

Tiêu chuẩn lựa chọn:

- Có giải phẫu bệnh lý khẳng định là ung thư nguyên phát ở phổi 
- Được làm xét nghiệm NGS bằng mẫu mô hoặc mẫu máu hoặc mầu dịch màng phổi, màng tim

Tiêu chuân loai trừ: Ung thư phổi loại tế bào nhỏ hoặc thần kinh nội tiết

2.2. Phương pháp nghiên cứu: Mô tả hồi cứu Phương pháp xét nghiệm thực hiện

- Mẫu: Nến đúc, dịch, máu

- Bộ hoá chất: New England BioLabs, Hoa Kỳ

- Thiết bị: Hệ thống giải trình tự gen thế hệ mới (next generation sequencing) MiniSeq, Illumina, Hoa Kỳ

- Kỹ thuật: Massively parallel DNA by next generation sequencing technology

- Đột biến khảo sát chính: Các đột biến liên quan đến ý nghĩa lâm sàng của các gen EGFR, KRAS, NRAS, ALK, BRAF, ROS1 được kiểm tra. Chỉ các đột biến có tần suất cao hơn tần suất phát hiện ( $5 \%$ với mẫu mô và $1 \%$ với mẫu $A D N$ tự do) được ghi nhận.

Thống kê và xử lý số liệu: Bằng phần mềm thống kê y sinh học

\section{KẾT QUẢ NGHIÊN CỨU}

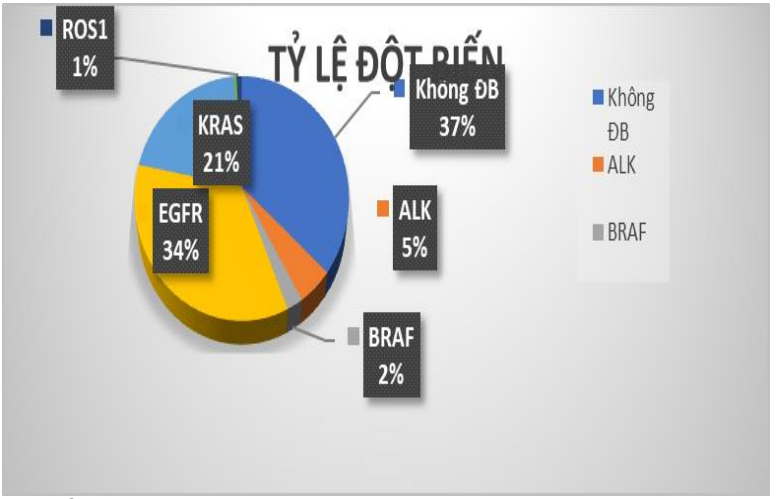

Biểu đồ 3.1. Phân tích kêt quả giải trình tự gen

Nhận xét: Đột biến KRAS chiếm 20,1\% (187/ 930 mẫu khảo sát)

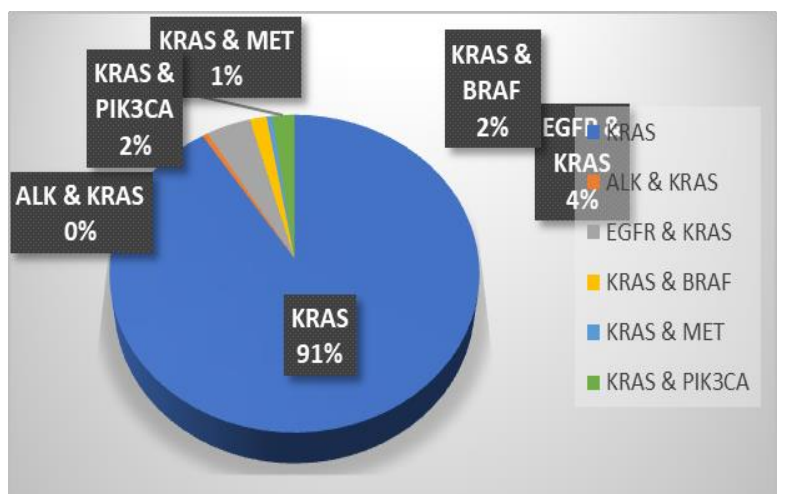

Biểu đồ 3.2. Phân bố bệnh nhân có đột biên KRAS

Nhận xét: $9 \%$ bệnh nhân đột biến KRAS có đồng đột biến một gen khác
Bảng 3.1. Đôt biến KRAS theo giới tính

\begin{tabular}{|c|c|c|c|}
\hline Row Labels & Nam & Nũ̃ & Grand Total \\
\hline ALK \& KRAS & 1 & 0 & 1 \\
\hline EGFR \& KRAS & 5 & 3 & 8 \\
\hline KRAS & 159 & 11 & 170 \\
\hline KRAS \& BRAF & 3 & 0 & 3 \\
\hline KRAS \& MET & 1 & 0 & 1 \\
\hline KRAS \& PIK3CA & 3 & 1 & 4 \\
\hline Grand Total & $\mathbf{1 7 2}$ & $\mathbf{1 5}$ & $\mathbf{1 8 7}$ \\
\hline \\
Nhận xét: Đột biến KRAS chủ yếu xảy ra ở nam
\end{tabular}

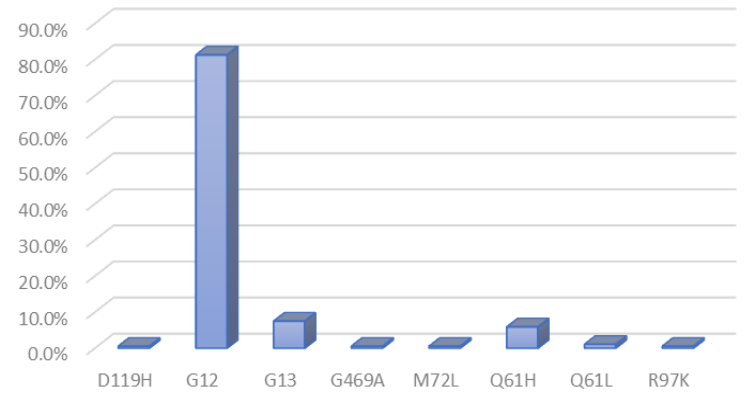

Biểu đồ 3.3. Phân bố vi trí đột biến KRAS

Nhận xét: Đột biến ở Codon 12 chiếm 81,3\%; codon 13 chiếm 18,7\%

\section{BÀN LUẬN}

Điều trị ung thư phổi không tế bào nhỏ giai đoạn tiến xa có rất nhiều tiến bộ trong hơn một thập kỷ nay. Trước đây, điều trị giai đoạn tiến xa chủ yếu là hóa trị liệu. Một số vấn đề gặp phải khi điều trị hóa chất là tỷ lệ đáp ứng, đặc biệt là đáp ứng hệ thần kinh trung ương và độc tính. Các điều trị nhắm đích giảm thiểu độc tính và có tỷ lệ đáp ứng cao hơn, nhất là trên hệ thần kinh trung ương. Chính bởi vậy, xét nghiệm phân tử để tìm ra đột biến hết sức quan trọng trong điều trị và tiên lượng đối với ung thư phổi không tế bào nhỏ giai đoạn tiến xa. Hiện nay tại nước ta, hai đột biến quan trọng nhất là đột biến EGFR và đột biến ALK vì chiếm tỷ lệ cao và có thuốc điều trị.

Gia đình gen ras gồm 3 loại KRAS, N-RAS, $\mathrm{H}$ RAS. RAS là một loại gen sinh ung thư nằm ở nhiễm sắc thể $12,6,1$, nó mã hoá cho một loại protein $\mathrm{G}$, có chức năng điều hòa đường truyền tín hiệu phân bào. Nhưng khi nó bị đột biến, sẽ mất khả năng kiểm soát sư phân bào, dẫn đến tế bào phân chia liên tục dấn đến ung thư. KRAS (Kirsten rat sarcoma 2 viral oncogen homolog) là một gen nằm trên nhánh ngắn của nhiễm sắc thể 12, với kích thước 46.148 cặp base, bắt đầu từ vị trí base thứ 25.357 .723 đển vị trí base thú 25.403.870. Gen KRAS cấu tạo gồm 6 exon, trong đó exon 2, 3, 4 chứa thông tin di truyền quy định đặc điểm của tế bào. Theo các nghiên 
cứu đột biến KRAS thường xảy ra ở Codon 12 , tỷ lệ cao hơn rất nhiêu so với Codon 13 và 61 . Nghiên cứu của chúng tôi cho kết quả tương tự với Codon 12 chiếm 81,3\%; codon 13 chiếm 18,7\%

Đột biến KRAS chiếm tỷ lệ khoảng 20-25\% ung thư biểu mô tuyến của phổi tại Bắc Mỹ, là đột biến thường gặp nhất tại đây [8]. Tại Việt Nam, tỷ lệ đột biến KRAS trong ung thư phổi chiếm khoảng 20\% [1]. Nghiên cứu của chúng tôi cũng cho kết quả tương tự thống kê tại Việt Nam với tỷ lệ đột biến KRAS là 20,1\%. Khác với đột biến EGFR và ALK, đột biến KRAS thường xảy ra ở nam giới, liên qua chặt chẽ với tình trạng hút thuốc. Theo tác giả Ahrendt SA, đột biến KRAS chiếm tỷ lệ 43\% ở bệnh nhân hút thuốc, trong khi tỷ lệ này là $0 \%$ ở nhóm không hút thuốc, $p=0,001[5]$. Trong nghiên cứu của chúng tôi, trong 187 bệnh nhân có đột biến KRAS thì 172 bệnh nhân là nam giới, chiếm tỷ lệ $92 \%$. Một tỷ lệ nhỏ (9\%) có đột biến KRAS kèm với những đột biến khác như EGFR (4\%); BRAF $(2 \%)$; MET (1\%), PI3KCA (2\%). Khi có kèm đột biến EGFR, những bệnh nhân có đột biến KRAS sẽ đáp ứng kém hơn với EGFR TKI so với những bệnh nhân khác $[7,8]$. Đột biến KRAS là một yếu tố tiên lượng xấu trong ung thư phổi. Theo y văn, những bệnh nhân có đột biến KRAS cũng liên quan tới tình trang đáp ứng kém với hóa tri và thời gian sống thêm ngắn $[4,6,8]$. Giả thiết này cân có nghiên cứu sâu tại Việt Nam hơn về tiên lượng của bệnh nhân ung thư phổi có đột biến KRAS.

\section{KẾT LUÂN}

- Đột biến KRAS chiếm tỷ lệ 20,1\%

- 9\% đột biến KRAS xuất hiện đồng thời với một đột biến khác (EGFR, ALK, BRAF, MET.
PI3KCA)

- Đột biến KRAS chủ yếu xảy ra ở nam giới chiếm tỷ lệ $92 \%$

- Đột biến ở Codon 12 chiếm 81,3\%; codon 13 chiếm $18,7 \%$

\section{TÀI LIẸU THAM KHẢO}

1. Anh-thu Huynh Dang, Vu-Uyen tran, ThanhTruong chan et al. Actionable Mutation Profiles of non-Small cell Lung cancer patients from Vietnamese population. Scientific Reports (2020) 10:2707|https://doi.org/10.1038/s41598-020-59744-3

2. Bos JL. Ras oncogenes in human cancer: a review. Cancer Res. 1989; 49:4682-4689. [PubMed] [Google Scholar]

3. Ding L, Getz G, Wheeler DA, et al. Somatic mutations affect key pathways in lung adenocarcinoma. Nature, 2008,455: 1069-1075.

4. Graziano SL, Gamble GP, Newman NB, et al. Prognostic significance of $\mathrm{K}$ ras codon 12 mutations in patients with resected stage I and II non-smallcell lung cancer. J Clin Oncol, 1999,17:668-675.

5. Ahrendt SA, Decker PA, Alawi EA, et al. Cigarette smoking is strongly associated with mutation of the Kras gene in patients with primary adenocarcinoma of the lung. Cancer, 2001,92: 1525-1230.

6. Mascaux $\mathbf{C}$, Iannino $\mathbf{N}$, Martin B, et al. The role of RAS oncogene in survival of patients with lung cancer: a systematic review of the literature with meta-analysis. Br ] Cancer, 2005,92:131-139.

7. Pao W, Wang TY, Riely GJ, et al. KRAS mutations and primary resistance of lung adenocarcinomas to gefitinib or erlotinib. PLoS Med, 2005,2:e17.

8. Eberhard DA, Johnson BE, Amler LC, et al. Mutations in the epidermal growth factor receptor and in KRAS are predictive and prognostic indicators in patients with non-small-cell lung cancer treated with chemotherapy alone and in combination with erlotinib. J Clin Oncol. 2005 Sep 1;23(25):5900-9. doi: 10.1200/JCO.2005.02.857. Epub 2005 Jul 25.PMID: 16043828

\section{ỨNG DUNG TÍNH HÚT ẨM CỦA AEROSIL TRONG BÀO CHẾ VIÊN NÉN BAO PHIM KIM TIỀN THẢO HÀM LƯỢNG CAO}

\section{Nguyễn Đăng Thoại ${ }^{1}$, Khưu Mỹ Lệ ${ }^{1}$, Nguyễn Mạnh Huy ${ }^{1}$}

\section{TÓM TẮT}

Mục tiêu: Bào chễ viên nén kim tiền thảo hàm lượng cao nhằm giảm số viên thuốc trong một lần uống, giúp cho việc dùng thuốc thuận tiện hơn.

${ }^{4}$ Trường ĐH Y khoa Phạm Ngoc Thạch

Chịu trách nhiệm chính: Nguyễn Đắng Thoại

Email: thoaind@pnt.edu.vn

Ngày nhân bài: 25/1/2021

Ngày phản biện khoa học: 24/2/2021

Ngày duyệt bài: 15/3/2021
Phương pháp nghiên cứu: Dược liệu kim tiền thảo được chế biến bằng phương pháp nấu cao, sau đó tạo hat để bào chế viên nén bao phim. Thành phần của viên gồm cao kim tiền thảo, Avicel, tinh bột, aerosil phối hợp ở các tỉ lệ khác nhau. Đánh giá chất lượng của viên nén theo phương pháp và chỉ tiêu chất lượng quy định trong dược điển Việt Nam V. Kết quả: Lượng cao khô kim tiền thảo trong 1 viên là $200 \mathrm{mg}$ (so với $120 \mathrm{mg}$ của viên lưu hành trên thị trường) và lượng aerosil là $0,4 \%$. Viên đạt yêu cầu về chỉ tiêu chất lượng viên nén theo chuyên luận của DĐVNV. Kết luận: Đã bào chế viên nén kim tiền thảo hàm 